\title{
Cherubism - Clinical case report and narrative review
}

\author{
Querubismo - Relato de caso clínico e revisão narrativa \\ Querubismo - Informe de un caso clínico y revisión narrativa
}

Received: 01/18/2021 | Reviewed: 01/25/2021 | Accept: 02/05/2021 | Published: 02/13/2021

\author{
Leonardo Alan Delanora \\ ORCID: https://orcid.org/0000-0002-3002-4420 \\ Universidade Estadual Paulista, Brazil \\ E-mail: leonardoaland@gmail.com \\ Ana Maira Pereira Baggio \\ ORCID: https://orcid.org/0000-0002-9474-5091 \\ Universidade Estadual Paulista, Brazil \\ E-mail: anamairabaggio@gmail.com \\ Nathália Januario de Araujo \\ ORCID:https://orcid.org/0000-0003-4859-0583 \\ Universidade Estadual Paulista, Brazil \\ E-mail: nathaliajanuario56@gmail.com \\ Idelmo Rangel Garcia-Junior \\ ORCID: https://orcid.org/0000-0001-8892-781X \\ Universidade Estadual Paulista, Brazil \\ E-mail: idelmo.rangel@unesp.br \\ Sabrina Ferreira \\ ORCID: https://orcid.org/0000-0002-9674-6709 \\ Universidade Estadual Paulista, Brazil \\ E-mail:drsassa@hotmail.com
}

\begin{abstract}
Cherubism is described as a rare and benign hereditary bone disease, characterized by a bilateral volumetric increase in the maxillary bones, with a greater predilection for males in childhood. Clinically, it presents as a volumetric enlargement of the mandible and, maxilla, which is generally painless, firm on palpation and varies in relation to size and extension. Its differential diagnosis is the Brown Tumor of Hyperparathyroidism and the Central Lesion of Giant Cells. The diagnosis is based on the assessment of clinical characteristics together with complementary exams. The objective of this study was to carry out a brief review of the literature and report a clinical case of this pathology in a 9-year-old child with a family history of cherubism, assessed through imaging, histopathological and karyotype exams, which continues to be assisted by the oral and maxilofacial surgery team of the Faculdade de Odontologia de Araçatuba - FOA Unesp since the treatment of the cherubism still does not have a definitive protocol.
\end{abstract}

Keywords: Cherubism; Pathology; Heredity.

\section{Resumo}

O Querubismo é descrito como uma doença óssea hereditária, rara e benigna, caracterizada por um aumento volumétrico bilateral dos ossos maxilares, com maior predileção pelo sexo masculino na infância. Clinicamente apresenta-se como um aumento volumétrico da mandíbula e maxila, geralmente indolor, firme a palpação e variam em relação ao tamanho e extensão. Possui como diagnóstico diferencial o Tumor Marrom do Hiperparatireoidismo e a Lesão Central de Células Gigantes. O diagnóstico é baseado na avaliação das características clínicas juntamente com os exames complementares. $\mathrm{O}$ objetivo deste trabalho foi realizar uma breve revisão de literatura e relatar um caso clínico desta patologia em uma criança de 9 anos com histórico familiar de querubismo, avaliada através de exames imaginológicos, histopatológicos e de cariótipo, que continua sendo assistida pela equipe de cirurgia e traumatologia bucomaxilofacial da Faculdade de Odontologia de Araçatuba - FOA Unesp visto que o tratamento do querubismo ainda não possui protocolo definitivo.

Palavras-chave: Querubismo; Patologia; Hereditariedade.

\section{Resumen}

El querubismo se describe como una enfermedad ósea hereditaria rara y benigna, caracterizada por un aumento volumétrico bilateral en los huesos maxilares, con mayor predilección por el sexo masculino en la infancia. Clínicamente se presenta como un agrandamiento volumétrico de la mandíbula y el maxilar, generalmente indoloro, firme a la palpación y variable en relación al tamanõ y extensión. Su diagnóstico diferencial es el Tumor Pardo del Hiperparatiroidismo y la Lesión Central de Células Gigantes. El diagnóstico se basa en la valoración de las características clínicas junto con exámenes complementarios. El objetivo de este estudio fue realizar una breve 
revisión de la literatura y reportar un caso clínico de esta patología en un niño de 9 años con antecedentes familiares de querubismo, evaluado mediante exámenes de imagen, histopatológicos y cariotipo, que continúa siendo asistido por el equipo de cirurgía y traumatología buccomaxilofacial de la Faculdade de Odontologia de Araçatuba - FOA Unesp ya que el tratamiento del querubismo aún no cuenta con un protocolo definitivo.

Palabras clave: Querubismo; Patología; Herencia.

\section{Introduction}

The term Cherubism was first reported in the literature by Dr. W. A. Jones in 1933 (Tiziani et al., 1999; Oliveira et al., 2008; Yalcin et al., 1999; López et al., 2016). It is a benign fibro-osseous disease, with an autosomal dominant hereditary character that affects both the maxilla and mandible bones (Tiziani et al., 1999; Dias \& Guedes, 1999; Fonseca et al., 2004; Oliveira et al., 2008; Yalcin et al., 1999; Marçolla et al. 2014; Cariati et al., 2017). It is considered a rare disease, with few reported cases and its etiology is still poorly understood (Oliveira et al., 2008; Yalcin et al., 1999; Marçolla et al. 2014) although believed that a developmental disorder in the formation of the mesenchyme may be a possible cause (Yalcin et al., 1999). Some researchers (Oliveira et al., 2008; Yalcin et al., 1999) believe that its etiology is associated with the gene linked to the development of the maxillary and mandibular bones and agree that lesions regress spontaneously at puberty (Tiziani et al., 1999; Dias \& Guedes, 1999; Chrcanovic et al., 2020; Cardoso et al., 2012, Beaman et al., 2004; Cariati et al., 2017). The reason for this has not yet been established and the most likely hypothesis is that sex hormones act on bone cells and normalize the situation (Oliveira et al., 2008).

\section{Methodology}

This study is a case report in a qualitative and descriptive way, associated with a narrative review of the literature, bringing relevant data available in the literature, regarding the pathology correlated to the clinical case presented of a 9-yearold male patient, with suspected cherubism and a positive diagnosis of cherubism in family history that was accompanied by the maxillofacial surgery and traumatology team at the Faculty of Dentistry of Araçatuba - UNESP. The Informed Consent Form was signed by the patient, following all protocols under the same consent form (Pereira et al. 2018 and Delanora et al. 2020).

\section{Review of Literature}

It is known that cherubism occurs in childhood, with a greater predilection for male children between three and four years of age, with its maximum development around nine years of age (Tiziani et al., 1999; Fonseca et al., 2004; Oliveira et al., 2008; Marçolla et al. 2014; López et al., 2016; Cariati et al., 2017).

Clinically, it presents as a volumetric enlargement of the mandible and maxilla, which is generally painless, firm on palpation and varies in relation to size and extension (Oliveira et al., 2008; Yalcin et al., 1999; Chrcanovic et al., 2020; López et al., 2016; Cariati et al., 2017). In the mandible, there is usually lesion at the angle up to the ascending branch and body of the mandible and the maxilla, affects the tuberosities (Oliveira et al., 2008). In addition, in some cases, abnormal eruption of permanent teeth, dental impaction and root resorption may occur. (Tiziani et al., 1999; Fonseca et al., 2004; Oliveira et al., 2008).

Radiographically, it appears as multiple radiolucent and multilocular lesions, with well-defined limits. Bone cortical expansion may occur symmetrically, giving the appearance of "soap bubbles" (Yalcin et al., 1999; Cardoso et al., 2012; Li \& Yu, 2006; López et al., 2016). Also characteristic of the cherubism is the dental displacement and impaction of teeth with the appearance of "floating teeth" within the radiolucent areas (Tiziani et al., 1999; Dias \& Guedes, 1999; Oliveira et al., 2008). 
The mandibular canal is displaced downward and the maxillary sinuses are opacified (returning to normal when the disease regresses) (Dias \& Guedes, 1999; Fonseca et al., 2004; Oliveira et al., 2008; Cardoso et al., 2012).

As for histological characteristics, it usually presents a vascularized lesion, rich in multinucleated giant cells of the osteoclastic type, in addition to vascular spaces within a fibrous connective tissue stroma (Cardoso et al., 2012).

The diagnosis is based on the clinical characteristics that accompany this deformity, in addition to complementary exams, such as panoramic radiography, computed tomography and magnetic resonance to observe tissues adjacent to the lesion (Chrcanovic et al., 2020; Marçolla et al., 2014; Cardoso et al., 2012; Beaman et al., 2004; Cariati et al., 2017).

The treatment of this disorder is usually based on the natural course of the disease and the clinical behavior of each patient, as the lesions tend to regress during the period of puberty (Tiziani et al., 1999; Fonseca et al., 2004; Oliveira et al., 2008; Marçolla et al. 2014; Cardoso et al., 2012; López et al., 2016).

It is believed that in most cases, at least one family member has the cherubism phenotype, as it is a pathology with an autosomal dominant hereditary character (Tiziani et al., 1999; Dias \& Guedes, 1999; Fonseca et al., 2004; Yalcin et al., 1999; Marçolla et al. 2014). In addition, studies have shown that two thirds of families that have this phenotype are followed by two or three generations that develop the disease, however there are also some sporadic cases reported in the literature (Tiziani et al., 1999; Li \& Yu, 2006; Beaman et al., 2004).

Tiziani et al. (1999) performed a genomic research in four families of two or three generations affected by the pathology and after carrying out the genetic mapping they found the locus for cherubism on the chromosome $4 \mathrm{p} 16.3$ and denominated SH3BP2, and the affected members of the four families had, for the most part, the typical characteristics of the cherubism, such as maxillary / mandible enlargement beginning in childhood or radiographic findings of multilocular radiolucent areas in the mandible. Point mutations in the SH3BP2 gene were found by Ueki et al. (2001) in 12 out of 15 families.

Beaman et al. (2004) selected 10 patients, 6 men and 4 women, with a diagnosis of cherubism based on histopathological characteristics, age of the patient and skeletal distribution of the lesions. All cases presented bilateral involvement of the mandible or complaint of facial edema and after analyzing the radiographic images, a characteristic pattern of expansive bone remodeling was found in all cases, internal trabeculation in $70 \%$ and a slightly sclerotic matrix in $60 \%$ of these patients.

Therefore, it is necessary to pay attention to the clinical and radiographic characteristics jointly with the histopathological findings and the patient's age for the correct diagnosis and conduct. Regarding the differential diagnosis of cherubism, there are the Central Lesion of Giant Cells and the Brown Tumor of Hyperparathyroidism (they have similar histological characteristics such as the presence of multinucleated giant cells, osteoclasts, fibrous connective tissue and hemorrhagic leakage), in addition to odontogenic cysts and tumors (Dias \& Guedes, 1999; Oliveira et al., 2008; Cardoso et al., 2012; Cariati et al., 2017).

Regarding the incidence, the authors agree that cherubism is a rare disease, which can be confirmed by the small number of cases present in the literature today. Therefore, it is important to improve studies on this pathology, so that it can be fully understood (Oliveira et al., 2008; Yalcin et al., 1999; Marçolla et al. 2014).

\section{Case Report}

A 9 -year-old male patient was referred to the Oral and Maxillofacial Surgery and Traumatology Clinic of the Faculdade de Odontologia de Araçatuba - UNESP, with suspicion of Cherubism and report of positive diagnosis for cherubism in the family history, presenting an excessive and disproportionate enlargement of the bilateral mandible and maxilla, observed during the clinical examination, more detailed during the extraoral examination, as shown in Figure 1. In the intraoral 
examination of the patient, it was noted the absence of some dental elements and dental impaction, in addition to an atresia palate, characteristics that can be seen in figure 2. The initial differential diagnosis was Brown Tumor of Hyperparathyroidism and Central Injury of Giant Cells.

Figure 1: Extraoral Aspect.

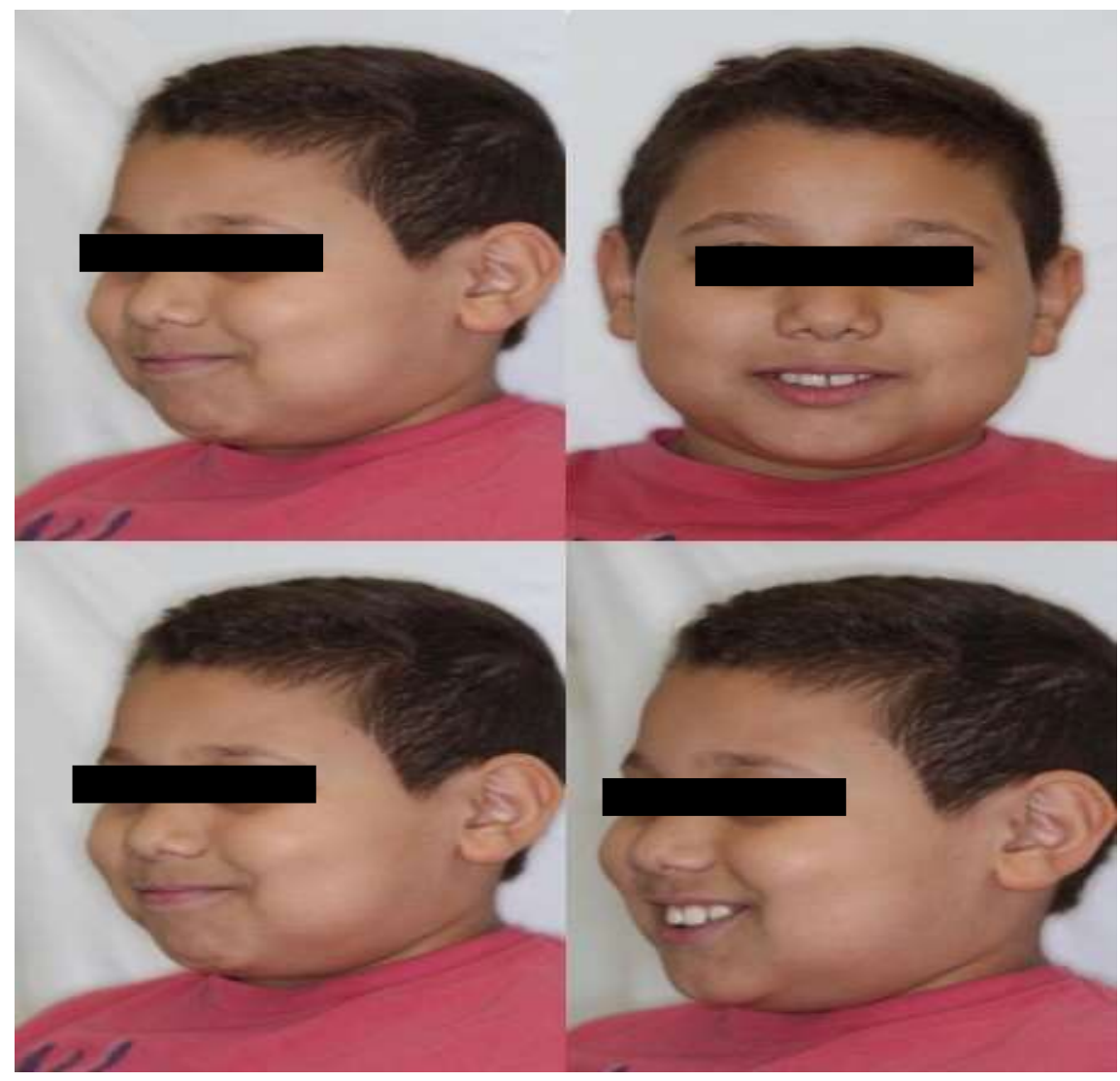

Source: Authors.

The Figure 1 shows the presence of facial deformity with bilateral mandibular and maxillary involvement of the patient, with a more pronounced increase on the right. 
Figure 2: Intraoral Aspect.

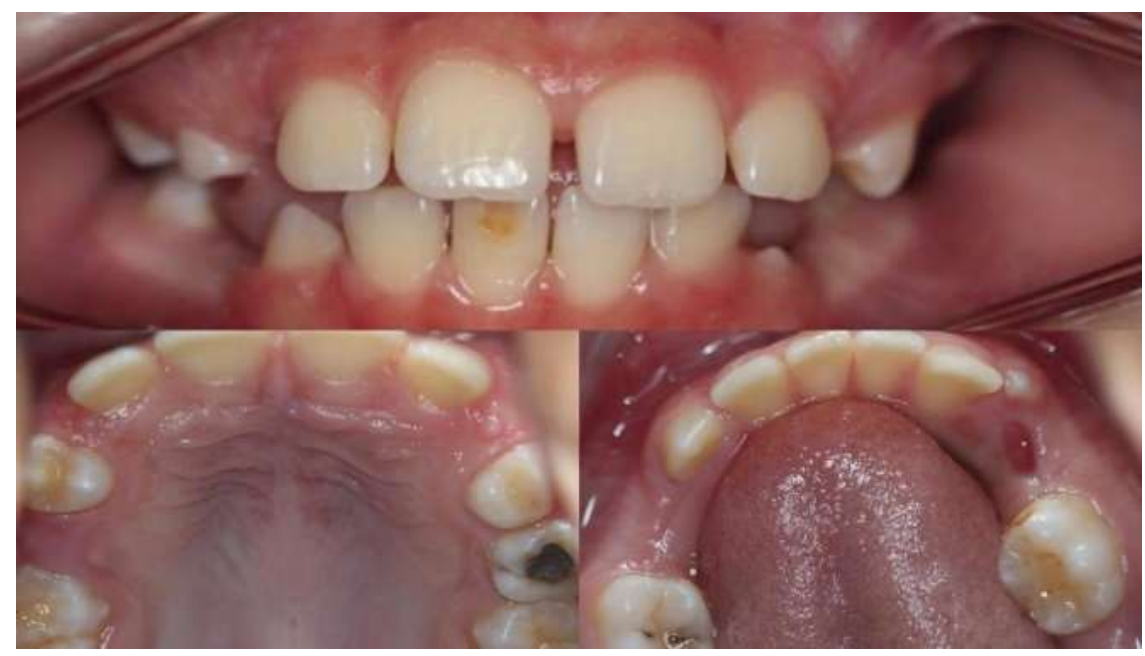

Source: Authors.

The intra-oral physical examination reveals the absence of some dental elements and dental impaction that can be caused by bone growth deficiency or early loss of primary teeth. The presence of an atresia palate and hypomineralization in the right lower central incisor is also noted, in addition to the presence of darkened grooves on the occlusal surface of the lower molars.

Radiographic (Figure 3), tomographic (Figure 4, 5 and 6) and karyotype tests were performed. Although SH3BP2 gene mutation is reported in the literature, the result of the patient's karyptype examination was negative.

Figure 3: Panoramic radiography.

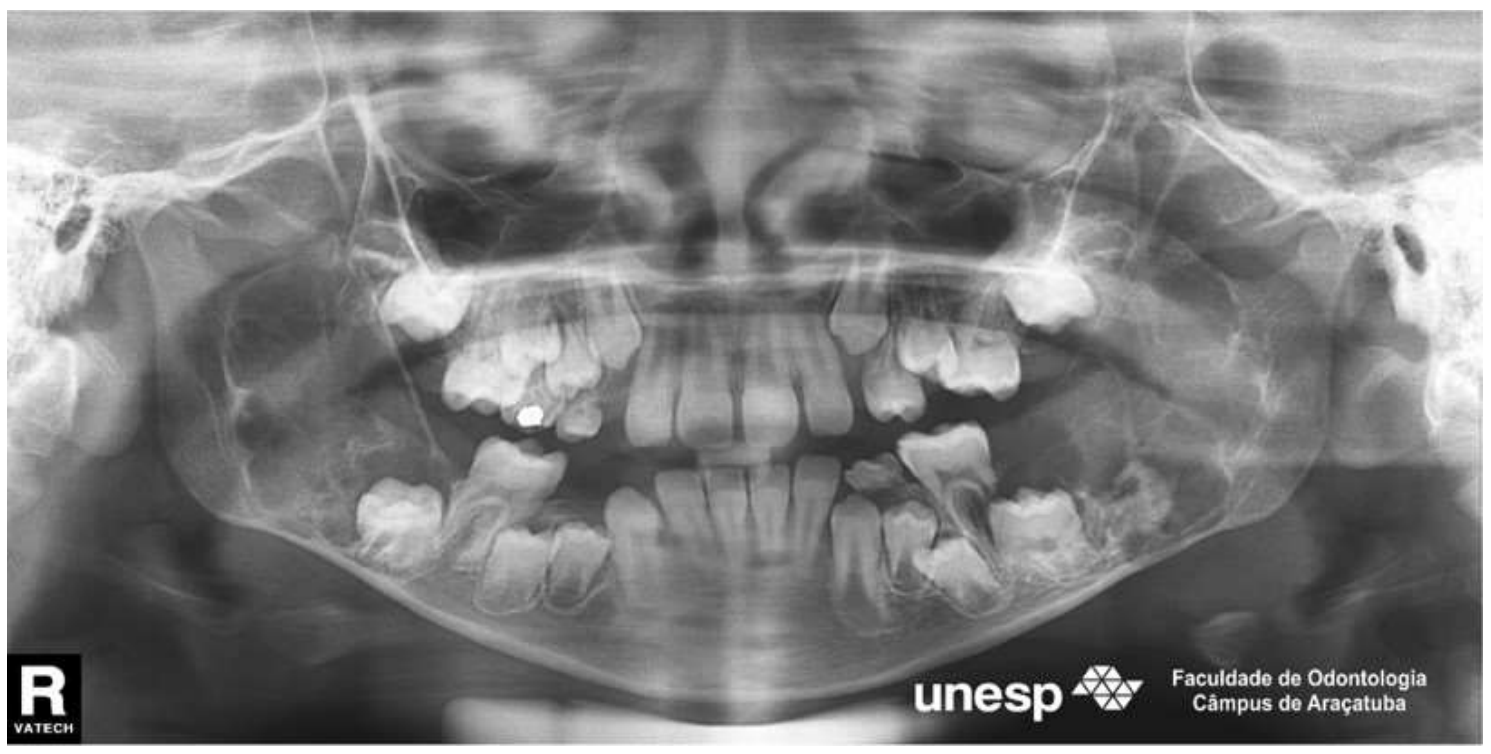

Source: Authors.

The panoramic radiographic image shows the abnormal eruption of permanent teeth and confirms dental impaction and root resorption of some elements, in addition to the presence of well-defined multilocular radiolucent areas and pneumatization of the maxillary sinuses. 
Research, Society and Development, v. 10, n. 2, 22510212085, 2021

(CC BY 4.0) | ISSN 2525-3409 | DOI: http://dx.doi.org/10.33448/rsd-v10i2.12085

Figure 4: Computed tomography.

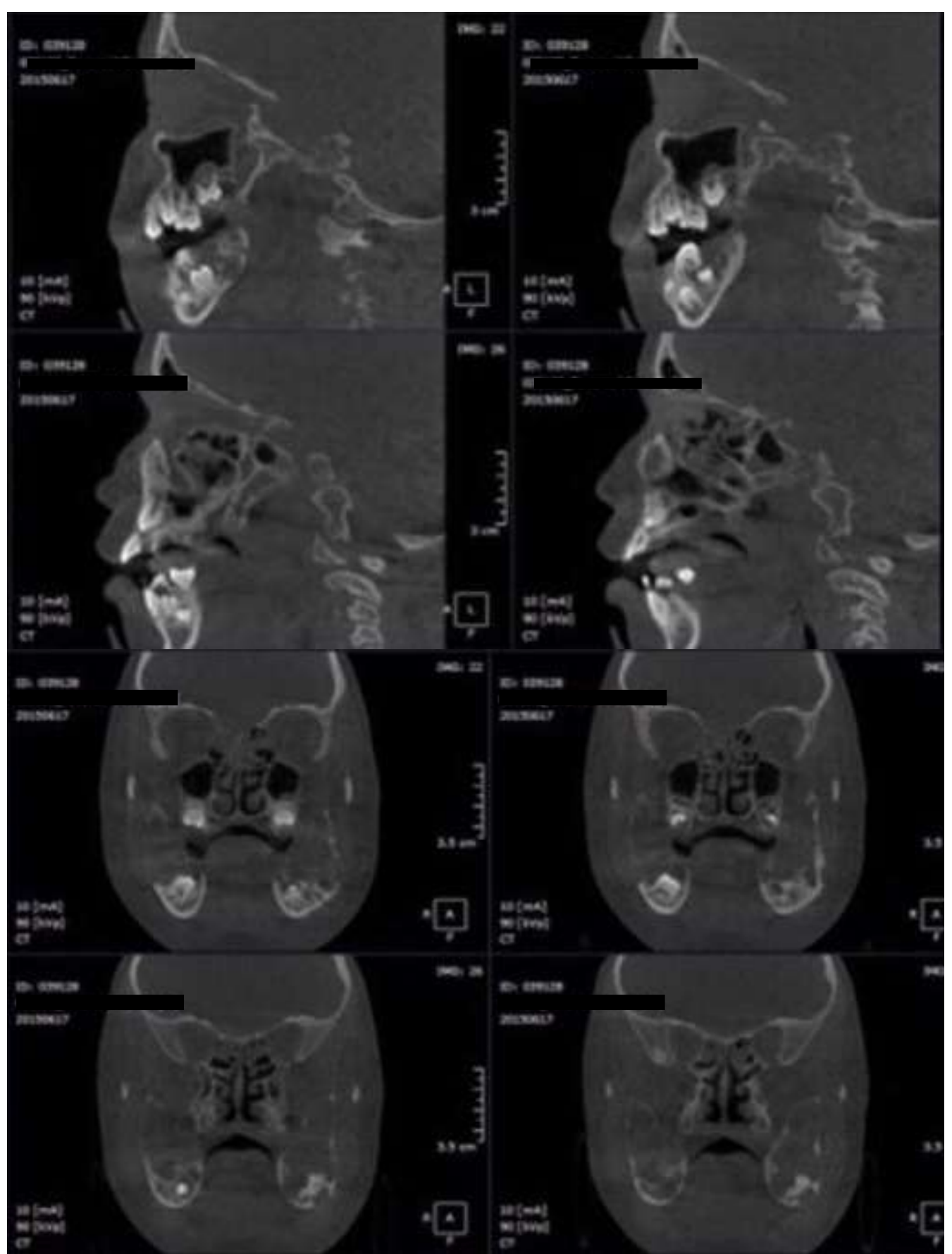

Source: Authors.

Lateral computed tomography shows involvement of both the maxilla and the mandible. The coronal section reveals the thinning of the bilateral mandibular bone cortex.

It is also possible to observe the presence of bilateral mandibular lesions with expansive bone remodeling. 
Research, Society and Development, v. 10, n. 2, 22510212085, 2021

(CC BY 4.0) | ISSN 2525-3409 | DOI: http://dx.doi.org/10.33448/rsd-v10i2.12085

Figure 5: Computed tomography.

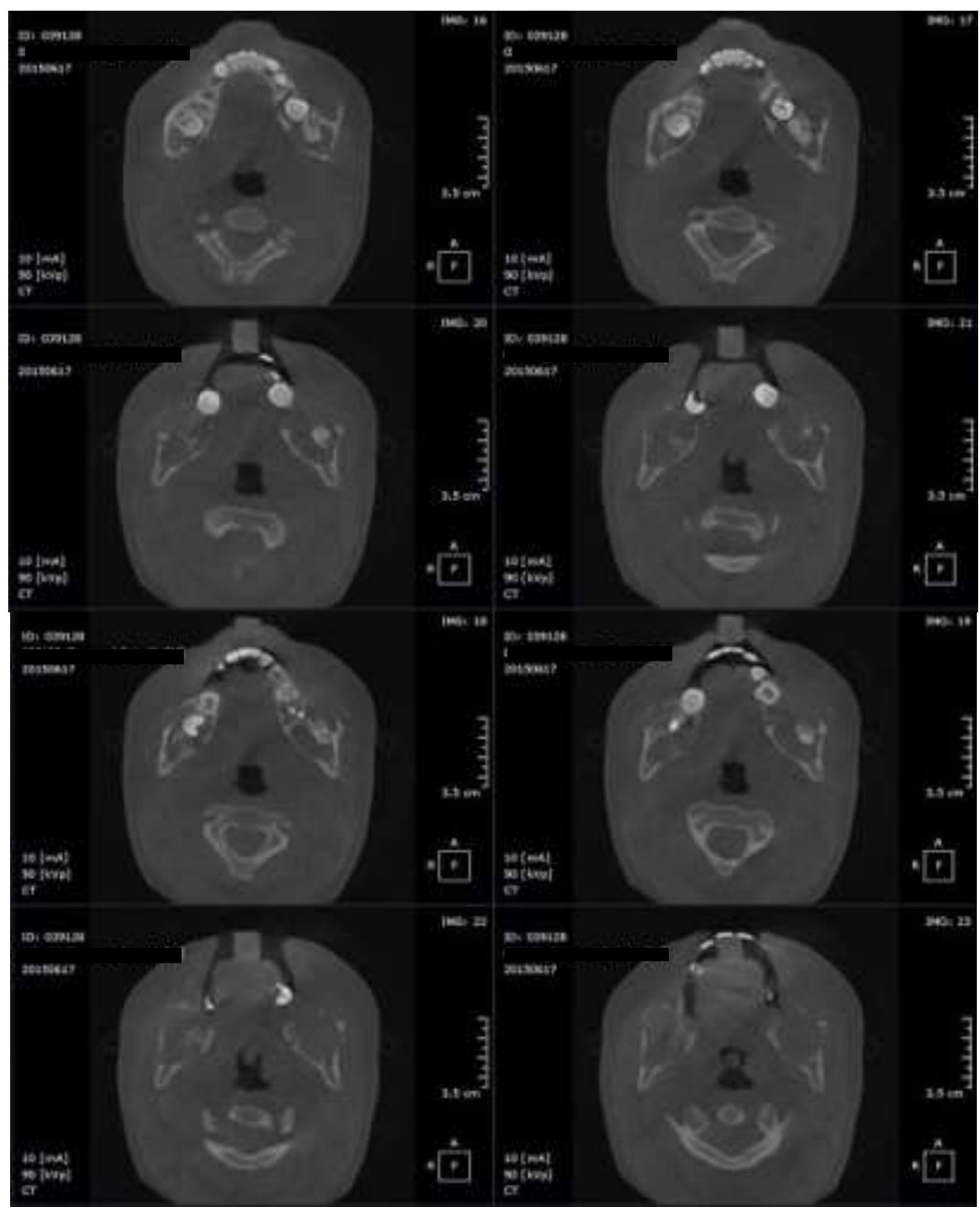

Source: Authors.

The axial section of the computed tomography reveals small mandibular lesions bilaterally and the presence of expansive bone remodeling. 
Figure 6: Reconstruction 3D.

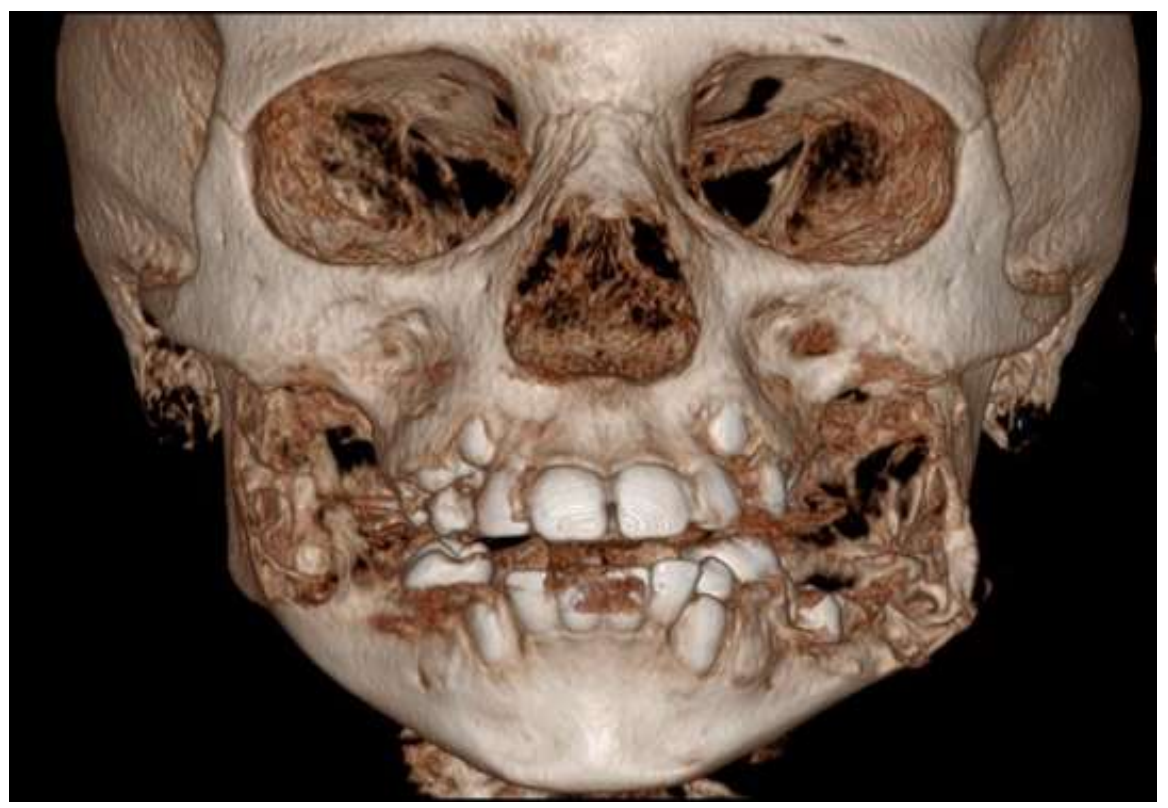

Source: Authors.

In three-dimensional reconstruction it is possible to observe extensive bone remodeling of the mandible and maxilla with internal trabeculation and the presence of fenestration in the bone plates of the jaws.

The proposed treatment was the clinical and radiographic monitoring of the patient by the team until adulthood, since this must be based on the natural course of the disease and the clinical behavior of each individual.

\section{Discussion}

Based on the age group, clinical evolution and imaging and histopathological findings, a definitive diagnosis of cherubism was given. The treatment consisted of monitoring the case and the patient continues to be assisted by the team since studies report that the disease progression stabilizes and tends to involution at the time of puberty. The patient is followed up by the bucomaxilofacial team at UNESP Araçatuba for 1 year, with no significant changes in clinical examinations, thus making the new radiographic recording linked to some clinical alteration or the next consultation with the team, if appropriate, aiming at non-exposure patient radiation unnecessarily.

The imaging findings of the present case are in line with those described in the literature (Beaman et al., 2004; Ozkan et al., 2003; Bianchi et al., 1987), as they showed a characteristic pattern of expansive bone remodeling in the mandible, which differentiates it from other bone lesions, such as fibrous dysplasia in which the lesions are located asymmetrically in the maxilla (Ozkan et al., 2003). Therefore, the importance of detailed evaluation of image exams, especially of computed tomography, which allows the accurate visualization of the involvement of all facial structures, is noteworthy, in addition to the importance of monitoring the case to assess the progression of the disease, since the cherubism does differential diagnosis with many other diseases and its treatment still does not have a defined protocol.

\section{Conclusion}

Cherubism is not yet fully understood and therefore there is no specific protocol for its treatment. Its prognosis is considered favorable due to the possibility of spontaneous remission, however it is important that in the face of a positive 
diagnosis, the patient has clinical and radiographic follow-up until adult age and that, as new cases and studies of this rare pathology appear, guide a possible consensus on the most appropriate conduct to be taken in these cases.

\section{Acknowledgments}

This study was financied in part by the Coordenação de Aperfeiçoamento de Pessoal de Nível Superior - Brasil (CAPES) - Código de Financiamento 001.

\section{References}

Beaman, F. D., Bancroft, L. W., Peterson, J. J., \& Kransdorf, M. J. (2004). Imaging characteristics of cherubism. Am J Roentgenol. 182(4), $1051-1054$.

Bianchi, S. D., Boccardi, A., Mela, F., et al. (1987). As aparições tomográficas computadorizadas do querubismo. Skeletal Radiol 16, 6-10.

Cardoso, J. A., Nogueira Neto, J. N., Ferreira. C. M., Arcadinos Leite, E., Gonçalves de Farias. (2012). Acometimento do querubismo em dois irmãos: relato de casos. RFO UPF 17(3), 342-346.

Cariati, P., Iglesias, F. M., Solís, J. F., Laseca, A. V., \& Lara, I. M. (2017). Cherubism. A case report. ScienceDirect, 13(6), $352-53$.

Chrcanovic, B. R., Guimarães, L. M., Gomes, C. C., \& Gomez, R. S. (2020). Cherubism: a systematic literature review of clinical and molecular aspects. Int J Oral Maxillofac Surg, 10(1), 10-16.

Dias, A. R. M., \& Guedes, A. M. L. (1999). Aspecto radiográfico do querubismo: relato de caso. Rev Bras Odontol, 56(3), $104-107$.

Delanora, L. A., Baggio, A. M. P., Farah, G. J., \& Faverai, L. P. Relationship between chemical dependents, blood pressure values and Dentist Surgeon $\begin{array}{llllll}\text { performance. Research, } & \text { Society } \quad \text { and } \quad \text { Development, [S. } \quad \text { l.], } & 9(8), & \text { e847986203, } 2020 . & 10.33448 / \mathrm{rsd}-\mathrm{v} 9 \mathrm{i} 8.6203 .\end{array}$ https://rsdjournal.org/index.php/rsd/article/view/6203.

Fonseca, L. C., De Freitas, J. B., Maciel, P. H., \& Cavalcanti, M. G. P. (2004). Temporal bone involvement in Cherubism: case report. Braz Dent J, 15(1), 7578.

Li, C., Yu, S. Uma nova mutação no gene SH3BP2 causa querubismo: relato de caso. (2006). BMC Med Genet 7, 84.

López, H. M. L., Picco, D. M. I., \& Lagunes, L. M. Querubismo, revisión de la literatura y reporte de un caso clínico. (2016). Rev Mex Cir Bucal Maxilofac, $12(3), 86-92$.

Marçolla, A. S., Barroso, F. T., Simões, N. M., Valerio, C. S., Alves Cardoso, C. A., Silva, A. I. V., \& Manzi, F. R. (2014). Diagnóstico tomográfico do querubismo: Relato de caso - Tomographic diagnosis of cherubism: casa report. Arquivo Brasileiro de Odontologia, 10(1), 40-45.

Oliveira, F. M. P., Cavasin Filho, J. C., Costa, C., \& Dib, L. L. (2008). Cherubism: clinical, radiographic and therapeutic aspects. Rev Inst Ciênc Saúde, 26(2), 254-257.

Ozkan, Y., Varol, A., Turker, N., Aksakalli, N., \& Basa, S. (2003). Clinical and radiological evaluation of cherubism: a sporadic case report and review of the literature. Intern Jour of Ped Otorhino. 67(9), 1005-1012.

Pereira, A. S., Shitsuka, D. M., Parreira, F. J., \& Shitsuka, R. (2018). Methodology of cientific research. Santa Maria: UAB / NTE / UFSM. https://repositorio.ufsm.br/bitstream/handle/1/15824/Lic_Computacao_Metodologia-Pesquisa-Cientifica.pdf?sequence=1\&isAllowed=y

Tiziani, V., Reichenberger, E., Buzzo, C. L., Niazi, S., Fukai, N., Stiller, M., Peters, H., Salzano, F. M., Raposo do Amaral, C. M., \& Olsen, B. R. (1999). The gene for cherubism maps to chromosome 4p16. Am J Hum Genet, 65(1), 158-166.

Ueki, Y., Tiziani,V., Santanna, C., Fukai, N., Maulik, C., Garfinkle, J., Ninomiya, C., do Amaral, C., Peters, H., Habal, M., Rhee-Morris, L., Doss, J. B., Kreiborg, S., Olsen, B. R., \& Reichenberger, E. (2001). Mutations in the gene encoding c-Abl-binding protein SH3BP2 cause cherubism. Nat Genet. 28(2), $125-126$.

Yalçin, S., Yalçin, F., Soydinç, M., Palanduz, S., Gunham, O. (1999). Gingival fibromatosis combined with cherubism and psychomotor retardation: a rare syndrome. J Periodontol, 70(2), 201-204. 